УДК 373.5:37.014:(811.161.2:37.026)

DOI:

Неллі Бондаренко, кандидат педагогічних наук, стариий науковий співробітник відділу навчання української мови та літератури

Сергій Косянчук, кандидат педагогічних наук, стариий науковий співробітник відділу дидактики Інституту педагогіки НАПН Украӥни

\title{
УКРАЇНСЬКА МОВА У ФОКУСІ ПЕРСПЕКТИВ РЕФОРМУВАННЯ СТАРШОӤ ШКОЛИ
}

Висвітлено важливі аспекти навчання украӥнської мови в 10 - 11 класах з огляду на перспективи реформування освіти. Акцентовано роль державної мови і всезагальну потребу досконало володіти нею. Проаналізовано теорію і практику навчання мови, перманентні зміни у змісті й структурі курсу на рівні програм. Визначено невирішені проблеми, невідкладні й перспективні завдання. Сформульовано вимоги до реформованої мовної освіти, принципи розбудови нової старшої школи. Спрогнозовано перспективи реформування теорії і практики навчання украӥнської мови.

Ключові слова: загальна середня освіта; реформування; навчання украӥнської мови; 10 - 11 класи. תim. 12.

Nelli Bondarenko, Ph.D.(Pedagogy), Senior Researcher of the Ukrainian Language and Literature Teaching Department Serhiy Kosyanchuk, Ph.D.(Pedagogy), Senior Researcher of the Didactics Department Institute of Pedagogy of National Academy of Pedagogical Sciences of Ukraine

\section{THE UKRAINIAN LANGUAGE IN THE FOCUSES OF PROSPECTS OF REFORMING THE HIGH SECONDARY SCHOOL}

The results of scientific research and pedagogical experience testify to the overloading of pupils of high secondary school with the special subject knowledge. At the same time, it was discovered that high secondary school pupils did not realize the importance of the acquired knowledge for the educational and practical activities. In addition, it was found that pupils have not fully developed an ability to apply knowledge of Ukrainian language into practice (some limitation of thematic, lexical, semantic, and contents aspects of speech of pupils of high secondary school; stylistic backhandedness; inadequate or inefficient use of language resources). The results of the external independent evaluation confirm that not all graduates of general secondary educational establishment have sufficient knowledge in Ukrainian language; they have a weak command of skilled practical language skills.

The article deals with the important issues of teaching the Ukrainian language in the 10-11grades in the context of modern educational transformations. The rules of the theory and practice of teaching the state language in the profile education is analyzed. The factors that complicate the process of learning the language in the high secondary school are determined. The permanent changes in the content and structure course at the program level are characterized. The program of Ukrainian language for the $10-11$ forms of general secondary education institutions with Ukrainian language education is analyzed. The problems are identified; their causes and possible consequences are explained; formulated the requirements for the reformed linguistic education. The conceptual and terminology apparatus of research, the core of which is the Ukrainian language competence, is specified. Conclusions were based on the study of the experience of reforming linguistic education in the leading countries of the world. They highlight the expediency of the creative use of elements of this experience, but taking into account the Ukrainian national specifics. The basic principles of reforming education in general and Ukrainian language education in particular in institutions of general secondary education are determined. The prospects for reforming the theory and practice of teaching the Ukrainian language are projected.

Keywords: general secondary education; reforming; learning the Ukrainian language; the 10 - 11 grades.

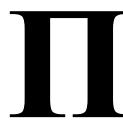
остановка проблеми. Еволюція суспільних пріоритетів, остаточний вибір цивілізаційного вектора розвитку країни, усвідомлення нацією своєї європейської ідентичності, глобалізаційні, зовнішні та внутрішні виклики актуалізували запит на зміну освітньої політики. Нинішнє реформування галузі, прийняття нової нормативно-правової бази мовної освіти концепції Нової української школи [6], Закону України "Про освіту" [4] - передбачають відмову від стереотипів, урахування вітчизняних здобутків, зарубіжного досвіду й загальносвітових тенденцій, реальних потреб особистості, забезпечення стабільного функціонування $\mathrm{i}$ поступального розвитку суспільства й держави. 
Нагромадження проблем у мовній освіті спонукає науковців і практиків до пошуку оптимальних шляхів їх розв'язання [1 - 3; 7; $8 ; 10-12]$.

Новітні тенденції розвиткугалузі узалежнюють здобуття освіти від інтересів самого учня, суспільства й держави. Освіта розглядається як інвестиція шкільної молоді в своє майбутнє. До такої золотої акції належить державна українська мова, що увійшла до ядра предметів, обов'язкових для вивчення всіма у всіх типах закладів загальної середньої освіти (З3СО). Результатом має стати сформована життева украӥнськомовна компетентність особистості. Адже українська мова - це мова національної ідентичності, засіб здобування інформації, знань $з$ усіх предметів, формування усіх без винятку компетентностей, вона пронизує їх і $€$ їх складником. На уроках 3 усіх предметів учні засвоюватимуть спеціальну термінологію, синтаксис наукового мовлення, що й збагачуватиме та розвиватиме їх українськомовну компетентність.

Однак, попри досягнення науки в царині методики навчання української мови, найвразливішою залишається старша школа [1; $2 ; 12]$. Це спричинено як об'єктивними, так $\mathrm{i}$ суб' єктивними негативними чинниками. Основні з-поміж них:

- складність діяльності володіння мовою носіями й описання цього явища на нинішньому рівні розвитку науки;

- нерозмежування дійсного володіння мовою i квазімовленнєвої діяльності;

- недостатне знання і врахування вітчизняних здобутків, досвіду закордоння й загальносвітових тенденцій;

- звуженість мотивації;

- орієнтація на ЗНО, програма якого далека від реальних мовних потреб випускників;

- розмитість цілей, кінцевих мети й освітніх результатів;

- розбіжність у поглядах науковців щодо мети, призначення, змістового наповнення і структури курсу української мови на завершальному шкільному етапі їі опанування;

- перевантаженість змісту;

- брак наступності між ступенями навчання 3 огляду на традиційну автономність початкової школи;

- недосконалість програм і підручників, де традиційно дублювався матеріал основної школи; “передозованість” риторикою, перебільшення ii значення для перспектив користування мовою на рівні стандарту випускниками 33СО;

- наявність надлишкової суто філологічної теорії з-поза меж шкільного етапу опанування мови (теорія риторики, система знань про стилістичні засоби мови);

- зумисна підлаштованість програми під конкретний підручник.

Напівреформована для перехідного періоду програма (2017) з української мови для 10-11 класів 33СО з навчанням українською мовою (рівень стандарту, 2017) не уникла дублювання. Вона передбачає вивчення вже згаданої риторики в недоцільному обсязі й неодноразово “пройдених", проте інакше згрупованих норм сучасної української літературної мови; містить неперевірені новації (роз'єднане подання пунктуаційних і синтаксичних норм, а також орфографічних одним блоком); надмірну кількість очікуваних результатів, серед яких невимірювані. Попри певну інакшість програми порівняно 3 попередніми, доцільність, оптимальність і всезагальна корисність закладеного у ній змісту небезсумнівна.

Водночас повноцінний зв'язок між цілями, змістом, результатами та інструментами оцінювання забезпечити складно з огляду на те, що критерії оцінювання мають розроблятися на концептуально інших засадах.

Аналіз останніх досліджень і публікацій. Трансформації у соціально-економічній i політичній сферах у різні періоди розвитку країни, зростання вимог суспільства до рівня і якості володіння державною мовою потребували перманентних змін узмісті мовної освіти, зокрема у старшій школі. Суть змін полягала в деідеологізації, гуманізації; осучасненні, увідповідненні змісту освіти сучасному стану розвитку науки, ІКТ; заміні наповнення мовного компонента; усуненні диспропорцій між вивченням теорії та іï застосуванням; спрощенні, розвантаженні від надлишкового матеріалу, який не має комунікаційної перспективи; компресії навчального матеріалу; заповненні лакун у мовленнєвому розвиткові учнів; структуруванні мовленнєвої діяльності; збагаченні новими реаліями й складниками, зокрема соціокультурною змістовою лінією, що забезпечує пізнавальне, ціннісне й змістове наповнення інтелектуально-мовленнєвої діяльності через занурення мови в культуру й соціум - середовище iii природного функціонування.

Невирішеність оприявнених проблем негативно позначається на освітньому процесі й рівні володіння державною мовою випускниками 33СО. Педагогічний досвід, шкільна практика, спостереження на уроках, аналіз усних i письмових висловлювань старшокласників, які завершили вивчення систематичного курсу 


\section{УКРАЇНСЬКА МОВА У ФОКУСІ ПЕРСПЕКТИВ РЕФОРМУВАННЯ СТАРШОӤ ШКОЛИ}

української мови в основній школі, свідчать про переобтяженість учнів спеціальними предметними знаннями i водночас про недостатню усвідомленість здобутих знань та не до кінця сформовану здатність застосовувати їх практично, певну тематичну, лексичну, смислову й змістову обмеженість їх мовлення; його неповну унормованість, структурну недосконалість, функціональну збідненість; стилістичну невправність мовців, недостатнє або невміле використання ними ресурсів мови. Результати ЗНО підтверджують, що далеко не всі випускники закладів загальної середньої освіти мають достатні знання й володіють навичками вмілого практичного користування мовою. 3 погляду вимог дидактики й методики має місце нереформованість науково-методичного забезпечення освітнього процесу відповідно до вимог часу; селекція методів навчання для елітних і звичайних закладів освіти; невідповідність організаційних форм, методів, засобів навчання особливостям сенситивного періоду; інерція використання застарілих методів і прийомів; неготовність частини вчителів застосовувати інноваційні підходи, технології навчання мови, зорієнтовані на високий освітній результат, а не просто на успішне складання ЗНО. Як наслідок, за результатами атестації з української мови 1362 претенденти на державну службу не спромоглися пройти атестацію щодо вільного володіння українською мовою (дані Національного агентства 3 питань державної служби за період 31 травня 2017 р. до 28 лютого 2018 р.).

Варто віддати належне науковцям Інституту педагогіки НАПН України Г. Єгорову, М. Красовицькому, О. Локшиній, Б. Мельниченку, В. Редьку та ін., які зробили вагомий внесок у дослідження стану і тенденцій розвитку старшої школи у провідних країнах світу - Франції, Великій Британії, ФРН, США, Іспанії. Наукові здобутки дослідників, зроблені ними висновки й рекомендації, спроектовані на українське національне підгрунтя, дають імпульс реформуванню вітчизняної освіти загалом і мовної зокрема з урахуванням світових надбань i новітніх тенденцій [5;9].

Водночас аналіз спеціальної літератури підтверджує брак фундаментальних і прикладних досліджень, присвячених науковим засадам навчання української мови саме шкільної молоді у реформованій освітній парадигмі $[3 ; 7 ; 8 ; 11$; 12]. Тому як було, так і залишається проблемою обгрунтування наукових засад мовної освіти, визначення змісту і структури курсу української мови у 10 - 11 класах, після того як в основній школі здобувачі повністю завершили вивчення мовної системи.

Мета статті - окреслити коло проблем мовної освіти шкільної молоді, яка перебуває на етапі професійного самовизначення, й визначити шляхи їх розв'язання.

Виклад основного матеріалу. Реформуючи надважливу старшу ланку освіти, необхідно зберегти, розвинути, збагатити і примножити поціновані у світі їі вартісні ознаки: традиції освіченості як ментального складника нації ще 3 часів Київської Русі; інтелектуальність; науковість, широту, конкретність і глибину змісту; цілісність, пластичність, високу якість та ін.

Компетентнісна спрямованість навчання української мови постає концептуальним фундаментом, що включає систему ідей, правил, фактичних даних і практичних рекомендацій для цілісного розв'язання проблеми наукового обгрунтування дидактико-методичної системи, раціонального добору змісту, визначення оптимальної структури, розроблення ефективної методики та педагогічних технологій для опанування старшокласниками мови в умовах профільного навчання [3; 4; 6; 12]. Освітній процес у 33СО та їх діяльність загалом має грунтуватись на засадах демократії, рівності, справедливості, плюралізму, солідарності, свободи. Науковці одностайні в тому, що старша школа має базуватись на таких засадничих принципах:

- воєдина реалізація суспільних та особистісних освітніх цілей;

- триєдина мета навчання, виховання і розвитку особистості;

- пластичність освітньої системи;

- свобода вибору освітньої траєкторії здобувачем;

- опора на унікальність, можливості особистості, досвід зі сфери іï інтересів;

- орієнтація на розвиток нестереотипного раціонального креативного стратегічного мислення;

- полікультурний контекст освіти;

- об'єктивний моніторинг перебігу освітнього процесу і якості освіти як результату.

Отже, успішне реформування змісту навчання української мови в старшій школі детермінується певними інваріантними вимогами. Це українська ідентичність; європейська перспектива; адекватність життєвим потребам людини, динамічним змінам, викликам сьогодення і прийдешнього; задіяність аспектів використання мови в різних сферах людської діяльності; зв'язки між мовою і фактами соціально-економічного 
життя; вмонтованість в інформаційний, культурний і соціальний контексти, у яких проявляється основна функція мови - бути засобом спілкування; врахування основних суспільних функцій мови і співвідносних із ними мовленнєвих дій, які є конкретним практичним виявом цих функцій.

Трансформуючи мовну освітуна завершальному етапі опанування української мови, слід застерегти від ревізії смислупоняття “володіння мовою” в бік спрощення, адже (за результатами проведених нами опитувань) серед основних очікувань здобувачів освіти навчитися: бути організованими і відповідальними за результати навчальних досягнень - $46 \%$; розвивати здатність знаходити порозуміння зі співрозмовником і вміти співпрацювати 3 іншими людьми - 45 \%; самонавчатися і здійснювати самостійний пошук потрібної навчальної та іншої інформації - 42 \%; критично мислити, формулювати самостійні судження, доходити правильних висновків $35 \%$; співвідносити свої потреби з наявними можливостями - $34 \%$; застосовувати здобуті знання, сформовані навички і набуті вміння у повсякденному житті - $33 \%$; швидко орієнтуватись у різних життєвих ситуаціях - $33 \%$; визначати пріоритети і шляхи реалізації цілей особистісного зростання - 30 \%. Як бачимо, всі очікування пронизані потребою формування українськомовної компетентності.

Прагнення учнів удосконалювати свою українськомовну компетентність виробляється шляхом надання їй глибокого особистісного смислу; створенням реально досяжних перспектив в оволодінні мовою, стимулюванням ініціативності, формуванням в освітньому середовищі культу конкурентоспроможної особистості.

Натепер триває імплементація панівних підходів до навчання мови - особистісно орієнтованого, компетентнісного, аксіологічного, діяльнісного, модифікація їх і співмірних із ними методів як під впливом досягнень науки, так і на основі врахування чинників, що стосуються володіння мовою. Це стимулює комбінування принципів і прийомів основних груп методів і водночас усуває недоліки попередніх, які вичерпали свій ресурс. На відміну від інших підходів, які поглинаються домінуючими і не враховують усіх чинників впливу на оволодіння мовою (природа самої мови, способи іiї опису, опанування мови, навчання мови тощо), зазначені підходи дають змогу охопити процес у всій його складності, віднайти оптимальні шляхи для досягнення поставленої мети. Залишаючись провідними, ці підходи мають бути збагачені специфічними для української лінгводидактики 3 метою всебічного охоплення аспектів мови як суспільного феномена, врахування культурного й соціального контекстів, у яких і проявляється основна функція мови - бути засобом спілкування.

Оновлена методика має грунтуватись на національних надбаннях, європейському i світовому досвіді, перспективних напрацюваннях і тенденціях. Застосування іiі має формувати не просто комуніканта, обмеженого меню життєвих потреб, а компетентну українськомовну особистість, спроможну вільно користуватися державною мовою в усьому багатоманітті їі функцій, освітньому потенціалові яких досі не приділялася належна увага. Дослідження, розпочаті в Інституті педагогіки НАПН України (2018 - 2020), спрямовані на розроблення компетентнісної методики навчання української мови у 10 - 11 класах (рівень стандарту). Ця методика передбачатиме формування українськомовної компетентності у змодельованому за науковими законами освітньому просторі, в координатах спеціально організованого освітнього процесу, лінгводидактичної системи, що реалізує конкретні мету і завдання, забезпечує відповідні організаційні, психолого-педагогічні, лінгводидактичні умови. Методику буде засновано на аксіологічному, особистісно орієнтованому, компетентнісному та діяльнісному підходах; провідних дидактичних і лінгводидактичних принципах; організаційних формах, методах, прийомах і засобах навчання i скеровано на досягнення конкретних життєво запитаних результатів. Вона реалізуватиметься поетапно через навчально-методичне забезпечення частково оновленого змісту навчання української мови у старшій школі; зазнбе впливу об'єктивних і суб'єктивних чинників.

Гіпотетично ефектив ність процесу розвит ку украӥнськомовної компетентності учнів 10-11 класів підвищиться за умов: урахування потреби випускників $33 \mathrm{CO}$ вільно володіти й користуватися державною мовою в усіх іi1 функціональних аспектах і сферах життєдіяльності; компетентнісної перебудови освітнього процесу на засадах сучасних підходів; формування українськомовної компетентності старшокласників у взаємозв'язку з набуттям ключових життєвих компетентностей, визначених у концепції Нової української школи й Законі України "Про освіту"; доцільного добору й оптимального поєднання організаційних форм, методів, прийомів і засобів навчання; створення системи завдань і вправ, спрямованих на 


\section{УКРАЇНСЬКА МОВА У ФОКУСІ ПЕРСПЕКТИВ РЕФОРМУВАННЯ СТАРШОӤ ШКОЛИ}

поетапне формування українськомовної компетентності майбутніх випускників; здійснення відкритого й об'єктивного контролю за освітнім процесом і його результатами.

Оновлюючи систему навчання державної мови у старшій школі на цьому етапі, необхідно вже зараз: розробляти стратегію модернізації іï у контексті нинішньої трансформації і прийдешнього реформування освіти; чітко сформулювати предметні мету, завдання й освітній результат; обгрунтовувати наукові засади курсу "Українська мова" для старшої школи; критерії добору змісту, оптимального для завершального етапу оволодіння мовою в 33СО; визначати зміст і структуру курсу, які буде втілено в новому стандарті мовної освіти.

В умовах компетентнісного навчання української мови зростає роль педагогічного працівника, завдання якого - розвивати пізнавальні здібності кожної особистості, незалежне раціональне стратегічне креативне мислення, життєво важливі компетентності, спонукати до досліджень та експериментування; створювати ситуації та перспективи успіху кожного; організовувати відкритий об'єктивний контроль за освітнім процесом, сформованістю навичок і вмінь, що дасть змогу відстежувати досягнення освітнього результату.

Висновки і перспективи подальших досліджень. Неперервні пошуки дидактів і словесників - науковців і практиків - свідчать про те, що резерви підвищення ефективності навчання української мови у старшій школі не вичерпано. Це - актуалізація вітчизняних здобутків, зокрема 3 дидактики, лінгводидактики, освітології, порівняльної педагогіки; вивчення можливостей перспективних для української освіти зарубіжних моделей із проекцією на національне підгрунтя; опора на інтелектуальний особистісний потенціал; розширення й збагачення мотивації пізнавальної діяльності; компетентнісна перебудова; орієнтація на зміст, що визначається життєвими потребами особистості, природою мови, системою мови і мовлення в їх діалектичній єдності; більш повна імплементація інноваційних підходів, їх еволюція, подальший розвиток; пропорційність інваріантного й варіативного складників змісту; оптимальні добір, групування, послідовність, дозування когнітивних інформаційних блоків і мовних одиниць у програмах і підручниках; системне врахування варіативності, індивідуальної та групової активності учнів в оволодінні мовою, а також диференціації, власної освітньої траєкторії, ритму, потреб особистісного розвитку; посилення самостійності учнів, що дасть змогу внести істотні зміни в структуру, організацію освітнього процесу, підвищити ефективність і якість освіти.

\section{ЛІТЕРАТУРА}

1. Бондаренко Н. Зміни в програмі з української мови для 10-11 класів та перспективи програмотворення / Неллі Бондаренко, Сергій Косянчук // Дивослово. - 2016. - № 7-8. - С. 23-27.

2. Бондаренко Н. В. "Перезавантаження" програм з мови: стан, виклики, перспективи / Н. В. Бондаренко // Дивослово. - 2015. - №7-8. - С. 14-17.

3. Васьківська Г. О. Формування ціннісносмислових орієнтацій учнів старшої школи засобами змісту сучасного підручника / Г. О. Васьківська, С. В. Косянчук // Проблеми сучасного підручника: зб. наук. праць. - Київ: Пед. думка, 2011. - Вип. 11. - С. 107-120.

4. Закон України "Про освіту" / Відомості Верховної Ради. - 2017. - № 38-39.

5. Локшина О. І. Зміст шкільної освіти в країнах СС: теорія і практика (друга половина XX - початок XXI ст.) : монографія / О. І. Локшина. - Київ: Богданова А. М., 2009. - 403 с.

6. Нова українська школа. Концептуальні засади реформування середньої школи [Електронний ресурс]. - Режим доступу: http:// mon.gov.ua/activity/education/zagalna-serednya/uasch-2016/konczepcziya.html

7. Основи критичного мислення: навч. посіб. для учнів старших кл. загальноосв. шк. [О. І. Пометун, Л. М. Пилипчатіна, I. М. Сущенко, I. О. Баранова]. - Тернопіль: Навчальна книга Богдан, 2010. - 216 с.

8. Пометун О. І. Енциклопедія інтерактивного навчання / О. І. Пометун. - Київ: СПД Кулінічев Б. М., 2007. $-144 \mathrm{c}$.

9. Старша школа зарубіжжя: організація та зміст освіти / [за ред. О. І. Локшиної]. - Київ: СПД Богданова А. М., 2006. - 232 с.

10. Українська мова для загальноосвітніх навчальних закладів з навчанням російською мовою [Електронний ресурс] / Н. В. Бондаренко, С. В. Косянчук, В. Л. Кононенко // Навчальні програми з української мови для загальноосвітніх навчальних закладів 3 навчанням мовою національної меншини та мов і літератур національних меншин для 10-11 класів (набирають чинності з 2018/2019 навчального року, затверджено наказом Міністерства освіти і науки України від 23.10.2017 № 1407). - Режим доступу: http://mon.gov.ua/activity/education/ zagalna-serednya/navchalni-programy.html (файл ukr-mova-10-11-z-navch-ros.doc). 
11. Фурман А. В. Теорія навчальних проблемних ситуацій: психолого-дидактичний аспект: монографія / А. В. Фурман. - Тернопіль : ACTOH, 2007. - $164 \mathrm{c}$.

12. Vaskivska H. O. Didactic possibilities of information and communication technologies in the process of development of educational environment in uppersecondaryschool/H. O. Vaskivska, S. V.Kosianchuk, H. M. Skyba // Information Technologies and Learning Tools. - 2017. - Vol 60. - №4. - P. 17-27.

\section{REFERENCES}

1. Bondarenko, N. \& Kosianchuk, S. (2016). Zminy v prohrami zukrainskoi movy dlia 10-11 klasiv ta perspektyvy prohramotvorennia [The changes in the Ukrainian language Program for 10-11 Grades, and prospects of program creation]. Dyvoslovo, no. 7-8, pp. 23-27. [in Ukrainian].

2. Bondarenko, N. V. (2015). "Perevantazhennia" prohram z movy: stan, vyklyky, perspektyvy ["Rebooting" of the language programs: the state, problems, and perspectives]. Dyvoslovo, no. 7-8, pp. 14-17. [in Ukrainian].

3. Vaskivska, H. O. \& Kosianchuk, S. V. (2011). Fotmuvannia tsinnisno-smyslovykh oriientatsiy uchniv starshoi shkoly zasobamy zmistu suchasnoho pidruchnyka [Formation of value-semantic orientations of senior pupils by means of modern textbooks]. Problemy suchasnoho pidruchnyka. Kyiv: Ped. dumka, no. 11, pp. 107-120. [in Ukrainian].

4. Zakon Ukrainy "Pro osvity". (2017). [Law of Ukraine "On Education"]. Vidomosti Verkhovnoi Rady. Kyiv, no. 38-39. [in Ukrainian].

5. Lokshyna, O. I. (2009). Zmist shkilnoi osvity v krainah YeS: teoriia i praktyka (druha polovyna $X X$ - pochatok XXI st.): monohrafiia [Content of school education in EU countries: theory and practice (second half of the XX - beginning of the XXI century)]. Kyiv: Bohdanova A. M., 403 p. [in Ukrainian].
6. Nova ukrainska shkola. Kontseptualni zasady reformuvannia serednioi shkoly. (2016). [New Ukrainian School. Conceptual Principles of Reforming Upper Secondary School]. Available at: http:// mon.gov.ua/activity/education/zagalna-serednya/uasch-2016/konczepcziya.html [in Ukrainian].

7. Pometun, O. I., Pylypchatina, L. M., Sushchenko, I. M. \& Baranova, I. O. (Ed.). (2010). Osnovy krytychnoho myslennia: navch. posib. dlia uchniv stsrshykh kl. zahalnoosv. shk. [Basics of critical thinking]. Ternopil: Navchalna knyha Bohdan, 216 p. [in Ukrainian].

8. Pometun, O. I. (2007). Entsyklopediia interaktyvnoho navchannia [Encyclopedia of interactive learning]. Kyiv: SPD Kulinichev B. M., 144 p. [in Ukrainian].

9. Starsha shkola zarubizhzhia: orhanizatsiia ta zmist osvity (2006). [Senior School of Abroad: Organization and Content of Education]. Kyiv: SPD Bohdanova A. M., 232 p. [in Ukrainian].

10. Bondarenko, N. V., Kosianchuk, S. \& Kononenko, V. L. (Ed.). (2017). Ukrainska mova dlia zahalnoosvitnikh navchaknykh zakladiv z navchanniam rosiiskoiu movoiu [Ukrainian language for general educational institutions with Russian language education].Available at: http://mon.gov.ua/ activity/education/zagalna-serednya/navchalniprogramy.html (файл - ukr-mova-10-11-z-navchros.doc) [in Ukrainian].

11. Furman, A. V. (2007).Teoriia navchalnykh problemnykh sytuatsiy: psykholoho-dydaktychnyi aspect: monohrafiia [Theory of educational problem situations: the psycho-didactic aspect]. Ternopil: ASTON, 164 p. [in Ukrainian].

12. Vaskivska, H. O., Kosianchuk, S. V. \& Skyba, H. M. (2017). Didactic possibilities of information and communication technologies in the process of development of educational environment in upper secondary school. Information Technologies and Learning Tools, vol. 60, no. 4, pp. 17-27. [in English].

Стаття надійшла до редакції 14.03.2018

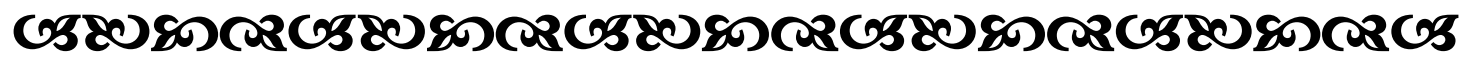

“Самостійні думки витіқають тільки із самостійно придбаних знань”.

Костянтин Уиинсъкий украйнсъкий педагог

“Dля успіху в житті уміння спілқуватися з людьми набагато важливіше, ніж володіння талантом".

Тюстав Яе Бон браниузъкий психолог, соиіолог

\section{G5808nc2058080}

